\title{
Radiation accidents - contribution to radioecological science and ecological lessons
}

\author{
R.M. Alexakhin \\ Russian institute of Agricultural Radiology and Agroecology, Obninsk, Russia
}

\begin{abstract}
The development of atomic industry and nuclear power engineering was accompanied by radiation incidents and catastrophes, some of these being rather large and resulting in radioactive contamination of the environment. Among the most important radiation accidents which have affected expanded areas are: the accident in the USSR in the South Urals with the formation of the East Urals Radioactive Trace in 1957, the accident in Sellafield, the United Kingdom in 1957, and the catastrophe at the Chernobyl NPP in 1986. The resulting radioactive traces - Emergency Radioactive Zones (ERZ) - have become the test sites for large-scale long-term radioecological investigations. The unique natural peculiarities of ERZs (wide variations in the environmental conditions - soil, plant-animal life, climatic factors, etc.) considering a wide range of man-made radionuclides (primarily biologically important ${ }^{90} \mathrm{Sr},{ }^{131} \mathrm{I}$ and ${ }^{137} \mathrm{Cs}$ ) released into the environment have made it possible to quantify the parameters of radionuclide migration via a large number of trophic chains in different natural environments (terrestrial, aquatic and other ecosystems). Information has been collected on radiation and post-radiation effects in various biota representatives in a wide range of doses and dose rates (especially at the population and ecosystem levels). Different countermeasures have been developed and applied on large territories for reducing exposure of the ERZ population and for remediation of the affected areas.
\end{abstract}

\section{INTRODUCTION}

It has been historically established that the development of nuclear power industry and engineering was accompanied by a number of radiation accidents and incidents, some of which resulted in a release of radioactive substances into the environment and formation of zones affected by radionuclides, Emergency Radioactive Zones (ERZ) (Table 1). The reasons of these radiation accidents and incidents associated with radioactive contamination of the environment were different - imperfection of nuclear technologies, human factor, political motivation of the accelerated development of nuclear industry.

ERZ were unique test sites for radioecological studies that significantly enriched radioecological science with information of paramount importance. The major advantage of ERZ radioecological investigations was the chance to study the following issues:

- Radionuclide migration in various ecosystems (terrestrial, aquatic, etc.) and landscapes (transecosystem transfer) and in a wide range of trophic chains in a long-term cycle;

- Radiation and post-radiation effects in biota in its habitat at different levels of organization of biological events (particularly emphasizing the organism, population and ecosystem levels);

- Radiation effects in different biota representatives in their natural environments in a wide range of dose rates and cumulative doses;

- Modifying effects of various natural and anthropogenic factors on biota exposed to ionizing radiations;

- Development of countermeasures to mitigate consequences of radioactive contamination of natural objects in real conditions.

Article published by EDP Sciences and available at http://www.radioprotection.org or http://dx.doi.org/10.1051/radiopro/20095146 
Table 1. Characteristics of the major radiation accidents with subsequent radionuclide release into the environment [1-4].

\begin{tabular}{|c|c|c|c|c|c|}
\hline Location & Date & $\begin{array}{l}\text { Main radio- } \\
\text { nuclides }\end{array}$ & $\begin{array}{c}\text { Total } \\
\text { release, } \mathrm{Bq}\end{array}$ & Area, $\mathrm{km}^{2}$ & $\begin{array}{c}\text { Criteria for } \\
\text { contaminated area } \\
\text { identification }\end{array}$ \\
\hline $\begin{array}{l}\text { River Techa, PP } \\
\text { "Mayak", USSR }\end{array}$ & 1949-1953 & $\begin{array}{l}{ }^{89} \mathrm{Sr},{ }^{90} \mathrm{Sr},{ }^{95} \mathrm{Zr}, \\
{ }^{103} \mathrm{Ru},{ }^{106} \mathrm{Ru}, \\
{ }^{137} \mathrm{Cs}\end{array}$ & $1.1 \cdot 10^{17}$ & - & - \\
\hline $\begin{array}{l}\text { PP “Mayak", (Ky- } \\
\text { shtym accident), } \\
\text { USSR }\end{array}$ & $\begin{array}{c}29 \text { September } \\
1957\end{array}$ & $\begin{array}{l}{ }^{89} \mathrm{Sr},{ }^{90} \mathrm{Sr},{ }^{95} \mathrm{Zr}, \\
{ }^{106} \mathrm{Ru},{ }^{137} \mathrm{Cs}, \\
{ }^{144} \mathrm{Ce}\end{array}$ & $7.4 \cdot 10^{16}$ & 23000 & $\begin{array}{l}\text { Area of }{ }^{90} \mathrm{Sr} \text { contami- } \\
\text { nation }>74 \mathrm{kBq} / \mathrm{m}^{2}\end{array}$ \\
\hline $\begin{array}{l}\text { Windscale (Sella- } \\
\text { field), United } \\
\text { Kingdom }\end{array}$ & $\begin{array}{c}10 \text { October } \\
1957\end{array}$ & $\begin{array}{l}{ }^{89} \mathrm{Sr},{ }^{90} \mathrm{Sr},{ }^{311} \mathrm{I}, \\
{ }^{137} \mathrm{Cs},{ }^{210} \mathrm{Po}\end{array}$ & $7.7 \cdot 10^{14}$ & 518 & $\begin{array}{l}\text { Excess of }{ }^{131} \text { I concen- } \\
\text { tration in milk } \\
3700 \mathrm{~Bq} / 1\end{array}$ \\
\hline Palomares, Spain & January 1966 & $\mathrm{Pu}$ & - & 2.6 & $\begin{array}{c}\text { Excess of density of } \\
\text { soil Pu contamination } \\
1.2 \mathrm{MBq} / \mathrm{m}^{2}\end{array}$ \\
\hline $\begin{array}{l}\text { Chernobyl NPP, } \\
\text { USSR }\end{array}$ & 26 April 1986 & $\begin{array}{l}{ }^{90} \mathrm{Sr},{ }^{131} \mathrm{I},{ }^{137} \mathrm{Cs} \\
\text { fresh products }\end{array}$ & $5.3 \cdot 10^{18}$ & 150000 & $\begin{array}{c}\text { Density of }{ }^{137} \mathrm{Cs} \\
\text { contamination above } \\
37 \mathrm{kBq} / \mathrm{m}^{2}\end{array}$ \\
\hline Goiania, Brazil & $\begin{array}{c}\text { September } \\
1987\end{array}$ & ${ }^{137} \mathrm{Cs}$ & $5.1 \cdot 10^{13}$ & - & $\begin{array}{l}\text { Density of }{ }^{137} \mathrm{Cs} \text { con- } \\
\text { tamination } 37 \mathrm{kBq} / \mathrm{m}^{2} \text {, } \\
\text { dose rate } 0.5-1 \mu \mathrm{Gy} / \mathrm{h}\end{array}$ \\
\hline
\end{tabular}

\section{RADIONUCLIDE MIGRATION IN THE ENVIRONMENT}

The major results from studying radionuclide migration in ERZ are as follows:

- Determination of transport parameters for a large number of anthropogenic radionuclides (mainly ${ }^{90} \mathrm{Sr}$ and ${ }^{137} \mathrm{Cs}$ ) via the main trophic chains in the environment to humans for different types of natural and agricultural ecosystems;

- Study of the role of different natural and anthropogenic factors in the radionuclide transfer via the trophic chains (biogeochemical conditions, meteorological conditions, etc.).

An essential phenomenon of the behavior of anthropogenic radionuclides in ERZ is changes in their species with time after their escape to the environment resulting in alteration of their mobility and biological availability on incorporation into the trophic chains.

The parameters of these changes have been estimated. The effective half-lives for some economically important chains (e.g., soil-milk) were shown to be $1.3-3$ years for "fresh" ${ }^{90} \mathrm{Sr}$ and ${ }^{137} \mathrm{Cs}$, which is significantly lower than their actual half-lives (about 30 years).

\section{IONIZING RADIATION EFFECTS ON THE ENVIRONMENT (BIOTA)}

Radioactive contamination of the environment following the two radiation events in the USSR, the Kyshtym (1957) and Chernobyl (1986) accidents, has resulted in the formation of radioactive trails with a vide variation in the fallout density, thereby causing irradiation of different natural and agricultural ecosystems in a wide range of dose rates and cumulative doses, including the exposure levels at which total destruction of some types of biogeocenoses was reported. This permitted the establishment of dose dependences of radiation induced effects at different levels of biological organization, from molecular to (which is especially important) population and ecosystem.

As a result of ERZ studies into ionizing radiation effects on ecosystems, the peculiar features of radiation damage processes and post-radiation recovery were described:

- Radiosensitivity of various natural ecosystems varies widely, least radiosensitive proved to be forest ecosystems (particularly coniferous forests); 
- Radioactive damage and post-radiation recovery of ERZ ecosystems is of a phase nature, with time after radioactive fallout, as dose rate is declining after the first period dominated by processes of radiation injury, comes the period of repair processes;

- Radioactive damage and post-radiation recovery of ERZ ecosystems depend on a large number of natural (meteorological conditions, environmental peculiarities, etc.) and anthropogenic (human activity) factors.

It has been noted that in the head parts of ERZ (with the highest contamination densities) the influence of anthropogenic activity (agricultural practice, tourism, hunting, fishery, etc.) can significantly overlap the impacts for evolution of ecosystems connected with the radiation factor (at low doses).

During ERZ studies a concept of radiation damage to ecosystems has been developed according to which the severity of radiation induced damage is dependent on changes in the factors themselves radiosensitivity and dose burdens. In the conditions when in contaminated ecosystems migrating radionuclides are a source of irradiation, the dose field proves to be very heterogeneous in both time and space, and in the ecosystem the so-called "hot niches" and biogeocenotic segments with increased irradiation are formed. These may be illustrated by crowns of "evergreen" coniferous trees, mesofauna of forest soils and litters, mesofauna of meadow root mat, part of roots and underground buds of plants in the top most affected soil horizons. In these conditions the maximum radiation damage occurs in the events when increased are doses to the most radiosensitive components of ecosystems (e.g., coniferous trees, invertebrates of forest soil and litter). For the ERZ conjugated data have been obtained on ionizing radiation effects on biota, on the one hand, and humans, on the other hand, which is crucial for the development of anthropocentric and ecocentric approaches. It has been found that irradiation of humans and non-human species is nonequidosal, with doses to human being two orders of magnitude higher than to other biota representatives.

As a result of ERZ studies, a basic paradigm of modern radioecology has been formulated: in radioactive contamination of the environment, the area where direct radiation injury of biota is observed is considerably smaller than the zone where the human economic activity is restricted (including the residence), because radionuclide concentrations in environmental objects (primarily in farm products) exceed the permissible standards.

\section{SYSTEM OF COUNTERMEASURES}

In ERZ, in real conditions, the effectiveness of a system of different countermeasures to reduce radionuclide accumulation in products and exposure of the population has been studied, which is essential in the remediation works on radioactively contaminated territories (Tables 2 and 3).

The Kyshtym and Chernobyl radiation accidents were recognized as rural ones (radionuclide containing agricultural products is the main source of additional accidental exposure; the rural population is the main contingent living in the accidental zone where irradiation of rural residents is

Table 2. Effectiveness of the main counter measures in plant production based on ERZ studies data, times [5-7].

\begin{tabular}{|c|c|c|c|c|c|}
\hline \multirow{2}{*}{ Counter measures } & \multicolumn{3}{|c|}{${ }^{137} \mathrm{Cs}$} & \multicolumn{3}{c|}{ Soils } \\
\cline { 2 - 6 } \multicolumn{2}{|c|}{} & \multicolumn{5}{c|}{$\mathrm{Sr}$} \\
\cline { 2 - 6 } & Mineral & Organic & Mineral & Organic \\
\hline \multicolumn{2}{|c|}{ Liming, 4-6 t/ha } & $1.5-3.0$ & $1.5-2.0$ & $1.5-2.6$ & - \\
\hline \multicolumn{2}{|c|}{ NPK application } & $1.5-2.0$ & $1.5-3.0$ & $0.8-1.2$ & - \\
\hline \multicolumn{2}{|c|}{ Manure, 50 t/ha } & $1.5-3.0$ & - & $1.2-1.5$ & - \\
\hline \multicolumn{2}{|c|}{ Liming + NPK } & $1.8-2.7$ & $2.5-4.0$ & - & - \\
\hline \multicolumn{2}{|c|}{ Zeolites } & $1.5-2.5$ & - & $1.5-1.8$ & - \\
\hline \multicolumn{2}{|c|}{ Plowing } & $8.0-12$ & $10-16$ & $2.0-3.0$ & - \\
\hline \multirow{2}{*}{ Pastures and meadow improvement } & Radical & $1.5-9.0$ & $4.0-16$ & $1.5-3.5$ & $3.0-5.3$ \\
\cline { 2 - 6 } & Surface & $2.0-3.0$ & $2.0-14$ & $2.0-2.5$ & $3.0-5.0$ \\
\hline
\end{tabular}


Table 3. Effectiveness of the main countermeasures in animal production based on ERZ studies data, times [5-7].

\begin{tabular}{|c|c|c|c|}
\hline \multirow{2}{*}{ Countermeasures } & \multicolumn{2}{|c|}{${ }^{137} \mathrm{Cs}$} & ${ }^{90} \mathrm{Sr}$ \\
\cline { 2 - 4 } & Milk & Meat & Milk \\
\hline \multicolumn{3}{|c|}{ Veterinary } \\
\hline Cs binders application & $1.5-6.0$ & $1.5-2.1$ & \\
\hline Sorbents application & 5.0 & 4.5 & 1.5 \\
\hline \multicolumn{2}{|c|}{ Zootechnical } & \\
\hline Preslaughter feeding with "clean" feeds & - & $2.0-1.5$ & \\
\hline Fodder additivies & $1.2-1.5$ & $1.5-3.1$ & $1.3-1.5$ \\
\hline Rational use of haylands and pastures & $1.5-15$ & $3.0-4.0$ & \\
\hline Fodder selection & 2.0 & 30 & \\
\hline
\end{tabular}

higher than that of urban population). On this basis, the introduction of a system of countermeasures in agriculture, as shown in Tables 2 and 3, provided a 3-5-fold decrease in the radionuclide concentration in food products (the same was a decrease in the dose of internal exposure). The remediation of agricultural lands was a crucial factor in overcoming consequences of these accidents.

\section{CONCLUSION}

The radiation accidents with the release of radionuclides into the environment and mitigation of their consequences required the solution of serious social problems. However, the formation of ERZ had become a unique site for radioecological investigations, which enriched this scientific discipline with the results of primary importance.

\section{References}

[1] Alexakhin R.M., L.A. Buldakov, V.A. Gubanov, Ye.G. Drozhko, L.A. Iljin, I.I. Kryshev, I.I. Linge, G.N. Romanov, M.N. Savkin, M.M. Saurov, F.A. Tikhomirov, Yu.B. Kholina. Large radiation accidents: consequences and protective countermeasures. Eds. L.A. Iljin and V.A. Gubanov. Moscow, IzdAT Publisher (2004).

[2] Medical-biological and ecological impacts of radioactive contamination of the river Techa. Eds A.V. Akleev and M.F. Kiselev. Moscow, RF Health Ministry. 532 p. (2000) (in Russian).

[3] Ecological and medical impacts of the 1957 radiation accident at the PP "Mayak". Eds A.V. Akleev and M.F. Kiselev. Moscow, RF Health Ministry. 296 p. (2001) (in Russian).

[4] Dunster H.J., Howells H., Templeton W.L. District surveys following the Windscale incident, October 1957. Proc. Second United Nations Intern Conf. On Peaceful Uses of Atomic Energy (Geneva, 1-13 September 1958). V.18. Waste Treatment and Environmental Aspects of Atomic Energy. Geneva, United Nations, 1958. P. 296-308.

[5] Fesenko S.V., R.M. Alexakhin, M.I. Balonov, I.M. Bogdevich, B.J. Howard, V.A. Kashparov, N.I. Sanzharova, A.V. Panov, G. Voigt, Yu.M. Zhuchenko. An extended critical review of twenty years of countermeasures used in agriculture after the Chernobyl accident. Sci. Total Environment, 383: 1-24. (2007).

[6] Prister B.S., R.M. Alexakhin, V.G. Bebeshko, I.M. Bogdevich, P.I. Zamostian, Ya.E. Kenigsberg, I.A. Likhtarev, V.A. Poyarkov, V.M. Shestopalov, A.F. Tsyb. The Chernobyl disaster: effectiveness of countermeasures for population protection experience of the international cooperation. Ukrainian Nuclear Society, Kiev (2007) (in Russian).

[7] Alexakhin R.M., B.S. Prister, The cradle of the Russian radioecology (to the $50^{\text {th }}$ anniversary of the Kyshtym accident). Radiation Biology. Radioecology, 48: 235-250 (2008) (in Russian). 